\title{
O RÓŻNYCH SPOSOBACH DĄŻENIA DO SPECJALIZACJI SĘDZIÓW ORZEKAJĄCYCH W SPRAWACH ADMINISTRACYJNYCH
}

\section{WPROWADZENIE}

Obserwując dokonujący się rozwój ekonomiczny, społeczny i technologiczny państw, truizmem jest stwierdzenie o rozrastaniu się regulacji prawa administracyjnego ${ }^{1}$. Proces ten pociaga za sobą stopniowe wykształcanie się podgałęzi tego prawa, które z racji na swoją specyfikę zaczynają nabierać cech autonomiczności. Coraz częściej powstają opracowania naukowe, w których akcentuje się kompleksowość prawa ochrony środowiska ${ }^{2}$, publicznego prawa gospodarczego ${ }^{3}$, prawa ochrony zabytkó $w^{4}$ czy prawa o szkolnictwie wyższym ${ }^{5}$. Prawo administracyjne tworzone jest $\mathrm{w}$ coraz szerszym zakresie na poziomie unijnym, co poszerza zasięg perspektywy uwzględnianej przez sądy administracyjne $^{6}$, określane także mianem sądów europejskich ${ }^{7}$. Wszystko to pociaga za sobą konieczność specjalizacji prawników administratywistów w tych obszarach wiedzy.

Od tego trendu nie mogą zostać zwolnione sądy, na których spoczywa ciężar rozstrzygania nierzadko skomplikowanych nie tylko pod względem faktycznym, lecz przede wszystkim prawnym spraw. Jednym z aspektów prawa do sądu, mającego swoje umocowanie zarówno w Konstytucji RP, jak i w prawie międzynarodowym, pozostaje prawo do sądu właściwego w znaczeniu fachowego, mającego wiedzę w rozstrzyganiu danej kategorii spraw ${ }^{8}$. Niewątpliwym

\footnotetext{
* Publikacja powstała w ramach stażu naukowego sfinansowanego w drodze konkursu ze środków Wydziału Prawa i Administracji Uniwersytetu im. Adama Mickiewicza w Poznaniu.

${ }^{1}$ Brohm (1991): 146; Zimmermann (2013): 45-47.

${ }^{2}$ Szerzej na temat argumentacji przemawiajaccej za wyodrębnieniem z prawa administracyjnego osobnej gałęzi prawa ochrony środowiska zob. Górski (2014): 39. Zob. też Korzeniowski (2014): $477 \mathrm{n}$.

${ }^{3}$ Rabska (2009): 591-592.

${ }^{4}$ Sienkiewicz (2017): $733 \mathrm{n}$.

${ }^{5}$ Izdebski (2019): 35-36.

${ }^{6}$ Kluth (2009): 151.

${ }^{7}$ Hohenecker (2015): 8-9.

${ }^{8}$ Wyrok TK z 19 października 2010 r., P 10/10, OTK-A 2010, nr 8, poz. 78; postanowienie TK z 5 kwietnia 2016 r., SK 41/15, OTK-A 2016/5. Postulat posiadania wysokich kompetencji przez sądy rozstrzygające o prawach i obowiązkach jednostki obecny jest także w literaturze zagranicznej. Zob. Serkov (2014): 494.
} 
plusem specjalizacji sędziowskiej pozostaje w tym kontekście minimalizacja zależności rozumowania sędziego od poglądów innych osób ${ }^{9}$. Rzetelność oraz prawidłowość rozstrzygnięć sądowych to jeden z czynników przesądzających o poziomie wiarygodności, jakim sądy cieszą się w społeczeństwie ${ }^{10}$. Z tej perspektywy punktem wyjścia poniższych rozważań jest założenie o konieczności zapewnienia zarówno przez prawodawcę, jak i organy władzy sądowniczej należytego, to znaczy odpowiedniego do rozstrzygania sporów o prawo, poziomu specjalizacji sędziów.

W ramach rozważań o charakterze prawnoporównawczym przedstawione zostaną różne sposoby osiągania tego celu, począwszy od kreacji specjalnych sądów administracyjnych, a skończywszy na wewnątrzsądowych sposobach zapewnienia wysokiego poziomu fachowości działalności orzeczniczej w systemach prawnych, które nie znają odrębnej gałęzi sądownictwa administracyjnego. W obrębie poniższej analizy uwzględnione zostaną także formułowane w literaturze zagranicznej argumenty przeciwne nadmiernej specjalizacji sędziów, w tym negatywne konsekwencje tego zjawiska, które - w ocenie autora - nie podważają wstępnej tezy badawczej, dotyczącej konieczności specjalizacji sędziów, tylko odnoszą się do sposobu realizacji tego wymogu.

\section{SPECYFIKA ROZSTRZYGANIA SPRAW ADMINISTRACYJNYCH PRZEZ SĄDY}

Traktując o potrzebie specjalizacji sędziów rozstrzygających sprawy administracyjne, na początku warto pochylić się przez chwilę nad samą ich natura, z której wypływa podstawowy argument przemawiający za koniecznościa dążenia do takiego sposobu wyboru sędziów, a następnie kształtowania ich kariery zawodowej, który będzie pozostawał w harmonii z ich działalnościa orzeczniczą.

Sięgając do początków kształtowania się sądownictwa administracyjnego w XIX-wiecznej Europie, podkreślano stopniową emancypację prawa administracyjnego w stosunku do prawa cywilnego ${ }^{11}$ oraz podwójna, publiczno-prywatną naturę sporów administracyjnoprawnych, które nie powinny pozostawać $\mathrm{w}$ gestii samej tylko administracji ${ }^{12}$. W ich obrębie styka się ze sobą interes indywidualny jednostki z interesem państwa. Rolą sądu pozostaje rozstrzygnięcie tego sporu bez mechanicznego dawania pierwszeństwa któremukolwiek ze wskazanych interesów. W nauce austriackiej zauważono, że zadanie to jest na tyle odmienne od działalności orzeczniczej sądów powszechnych, że konieczne pozostaje utworzenie osobnych sądów prawa publicznego ${ }^{13}$. Myśl ta zachowuje swoją aktualność po dziś dzień. Specyfika działalności orzeczni-

\footnotetext{
${ }^{9}$ Legomsky (1990): 8-9.

${ }_{10}$ Millgramm (2008): 822-823.

11 Menger (1963): 727.

12 Brohm (1991): 138.

13 Oberndorfer (1983): 25-26.
} 
czej sądów administracyjnych, które kontrolują administrację publiczna, pozostaje na tyle szczególna, a zarazem nieuchwytna, że nawet jej zastapienie utworzeniem odrębnych wydziałów orzeczniczych w sądach powszechnych nie oznaczałoby sprawowania wymiaru sprawiedliwości w taki sam pogłębiony i zarazem fachowy sposób.

U podstaw podwójnej natury sporów administracyjnych leżą dwie funkcje sądowej kontroli administracji, do których należy ochrona praw jednostki oraz ogólnego porządku prawnego. Obie z nich ujawniły się już w XIX w., w ramach odrębnych modeli sądowej kontroli administracji wykształconych w Prusach oraz państwach południowoniemieckich ${ }^{14}$. Współcześnie w doktrynie niemieckiej dominuje ujęcie subiektywne, zorientowane na ochronę interesu prawnego jednostki w sporze z administracja publiczna ${ }^{15}$. Dzięki ochronie prawnej sprawowanej przez sądy administracyjne obywatel w sporze z państwem nie jest pozostawiony samemu sobie ${ }^{16}$. Jednocześnie zauważa się, że rolą sąów administracyjnych nie jest ograniczanie uprawnień władczych państwa, tylko wyznaczanie im takich ram, w których będą one zgodne z prawem ${ }^{17}$. Wynika z tego, że obie funkcje nie powinny być przedstawiane jako przeciwstawne sobie, tylko wzajemnie się dopełniajace ${ }^{18}$. Tożsama refleksja formułowana jest w polskiej doktrynie na podstawie regulacji p.p.s.a. ${ }^{19}$

Podwójna natura sporów administracyjnych wpływa na szczególną pozycję sądów, które je rozstrzygają w ramach trójpodziału władzy. Konsekwencja tej pozycji jest specyfika sądowej kontroli administracji. Sądy, rozstrzygając spory publicznoprawne, nie powinny wkraczać w domenę władzy wykonawczej, ograniczając się do weryfikacji zgodności z prawem jej poczynań ${ }^{20}$. Współcześnie jednak coraz częściej dopuszcza się taką ingerencję przez wydawanie przez sądy rozstrzygnięć co do meritum sprawy administracyjnej, co usprawiedliwia się względami efektywności sądowej kontroli ${ }^{21}$, zacierania się granic pomiędzy trzema władzami ${ }^{22}$ oraz nowym spojrzeniem na trójpodział władzy ${ }^{23}$.

${ }^{14}$ Podczas gdy w modelu pruskim nacisk położony był na ochronę obiektywnego porządku prawnego, a jedynym sądem w pełni niezależnym od administracji publicznej był Oberverwaltungsgericht w Berlinie, w modelu południowoniemieckim pierwszorzędną rolę odgrywała ochrona praw podmiotowych jednostki, a tamtejsze sądy były w pełni niezależne od władzy wykonawczej. Zob. Menger (1963): 727. Zob. też Mehde (2010): 386-390; Brohm (1991): 138-139.

15 Jego wyrazem jest brzmienie $§ 42$ ust. 2 Verwaltungsgerichtsordnung (BGBl. 1991 I, s. 686 ze zm.), stosownie do którego wszczęcie postępowania przed sądem administracyjnym uzależnione jest od naruszenia interesu prawnego skarżącego przez wydanie, odmowę wydania albo zaniechanie wydania aktu administracyjnego.

16 Steiner (2012): 134.

17 Steiner (2012): 1450; Hermanns (2002): 20.

18 Maier (2015): 114-115; Rennert (2019): 594.

19 Ustawa z 30 sierpnia 2002 r. - Prawo o postępowaniu przed sądami administracyjnymi

(Dz. U. 2018, poz. 1302 ze zm.). Zob. Tarno (2006): 24-30; Piątek, Skoczylas (2016): 54.

${ }^{20}$ Pogląd ten prezentowany jest od lat w literaturze polskiej. Zob. Hauser, Drachal, Mzyk (2003): 22-23; Piątek, Skoczylas (2016): 54.

${ }^{21}$ Holoubek (2017): 12-13.

22 Jabloner (2001): 138-139.

23 Dlatego w ocenie Mehde, aktywizm sędziowski (judicial activism) jest dla sądu mniej ryzykowny aniżeli sędziowska powściagliwość (judicial restraint). Zob. Mehde (2010): 390. 
Wszystkich wskazanych powyżej procesów sędzia orzekajacy w sprawach administracyjnych powinien być w pełni świadomy, ważąc interes publiczny i prywatny w konkretnej sprawie, w tym poszukując rozstrzygnięcia godzącego oba interesy bądź dającego priorytet jednemu z nich przy jednoczesnym wyraźnym wskazaniu motywów takiego rozstrzygnięcia.

\section{KREACJA SZCZEGÓLNYCH GAEĘZI SĄDOWNICTWA JAKO SPOSÓB NA ZAPEWNIENIE SPECJALIZACJI WŚRÓD SĘDZIÓW}

Z ustrojowego punktu widzenia sposobem zapewnienia specjalizacji sędziów rozstrzygających sprawy administracyjne jest utworzenie odrębnych gałęzi sądownictwa administracyjnego, a niekiedy obok ogólnych sądów administracyjnych - także sądów szczególnych, socjalnych oraz finansowych $^{24}$.

Rozbudowany system sądownictwa występuje w Niemczech. Na jego czele zgodnie z art. 95 ust. 1 Ustawy zasadniczej (Grundgesetz) ${ }^{25}$ znajduje się pięć równych rangą oraz pozycją ustrojową sądów federalnych ${ }^{26}$, w tym obok Federalnego Sądu Najwyższego (Bundesgerichtshof - BGH), Federalny Sąd Administracyjny (Bundesverwaltungsgericht - BVG), Federalny Sąd Socjalny (Bundessozialgericht - BSG), Federalny Sąd Pracy (Bundesarbeitsgericht BAG) oraz Federalny Sąd Finansowy (Bundesfinanzhof - BFH). Do grona sądów administracyjnych zaliczane są trzy spośród wskazanych sądów, mianowicie BVG, BFH oraz BSG wraz z podporządkowanymi im sądami niższych szczebli ${ }^{27}$. Dla ochrony jednolitości orzecznictwa sądowego funkcjonuje, zgodnie z art. 95 ust. 3 GG, wspólny senat wszystkich wskazanych powyżej sądów federalnych.

Rozwinięta struktura sądownictwa administracyjnego występuje także w Austrii ${ }^{28}$, gdzie począwszy od wejścia w życie reformy sądownictwa administracyjnego, to znaczy od 1 stycznia $2014 \mathrm{r}^{29}$, istnieje model określany mianem 9+2, w skład którego wchodzi 9 krajowych sądów administracyjnych I instan-

24 Sądami tymi nie są jednostki tworzone na potrzeby szczególnych stanów i sytuacji, przykładowo stanu wojennego, tylko sądy tworzone dla rozpatrywania szczególnego rodzaju spraw. Zob. Serkov (2014): 496-497.

${ }^{25}$ Ustawa zasadnicza Republiki Federalnej Niemiec z 23 maja 1949 r., BGBl. 1949, 1 ze zm. (dalej jako: GG).

${ }^{26}$ Jak podkreśla się w doktrynie niemieckiej, przejawem tej równości jest równy status urzędniczy sędziów, w tym ich uposażenie. Zob. Heusch (2014): 2405.

${ }^{27}$ Hermanns (2002): 20-25. Sądami tymi są w ramach sądownictwa ogólnego Verwaltungsgerichte i Oberverwaltungsgerichte, w ramach sądownictwa socjalnego Sozialgerichte oraz Landessozialgerichte, a w obrębie sądownictwa finansowego Finanzgerichte. O ile zatem sądownictwo ogólne i socjalne jest trójszczeblowe, o tyle finansowe jedynie dwuszczeblowe.

${ }_{28} \mathrm{~W}$ doktrynie wskazuje się, że jedną z inspiracji do rozbudowy systemu sądownictwa był przykład oraz doświadczenia niemieckie. Zob. Kofler, Summersberger (2014): 625-626.

29 Szerzej zob. Faber (2013): 18-21; Pabel (2013): 10-13, Steiner (2014): 107-130. 
cji oraz dwa sądy federalne I instancji, w tym Federalny Sąd Administracyjny (Bundesverwaltungsgericht) oraz Federalny Sąd Finansowy (Bundesfinanzgericht). Kontrolę instancyjną nad orzeczeniami tych sądów sprawuje Trybunał Administracyjny (Verwaltungsgerichtshof).

W doktrynie obu państw zauważa się, że rozbudowanie struktury sądownictwa administracyjnego jest rezultatem rozwoju wiedzy, której poziom stale wzrasta $^{30}$. Wskazuje się także na stopniowy wzrost zadań spoczywających na państwie oraz łącząca się z tym konieczność zapewnienia fachowej ochrony prawnej obywatelom ${ }^{31}$. Obrazowo rzecz ujmując, podkreśla się, że sędziami sądów administracyjnych powinny zostawać osoby, które ,już świat zobaczyły", to znaczy mające doświadczenie zawodowe w innym obszarze aniżeli samo tylko sądownictwo ${ }^{32}$.

Mniej rozbudowany system, obejmujący jedną ogólną gałą́ sądownictwa administracyjnego, obok Polski występuje w Szwecji i we Włoszech. Podczas gdy w Szwecji jest on trójstopniowy ${ }^{33}$, we Włoszech od wyroków sądów administracyjnych I instancji przysługuje apelacja tylko do Rady Stanu ${ }^{34}$. Tak samo jak w Niemczech i w Austrii, w obu wymienionych krajach dostrzegana jest potrzeba specjalizacji sędziowskiej. Konstytucja Królestwa Szwecji stanowi, że przy obsadzaniu stanowisk sędziowskich należy kierować się wyłącznie obiektywnymi przesłankami, takimi jak fachowość i kwalifikacje kandydatów ${ }^{35}$. Potrzeba posiadania przez sędziów sądów administracyjnych specjalistycznych kwalifikacji dostrzegana jest w literaturze włoskiej ${ }^{36}$.

Z kreacją odrębnych gałęzi sądownictwa łączy się osobny sposób ścieżki dochodzenia do zawodu sędziego sądu administracyjnego. Przykładami w tej materii sa rozwiązania ustrojowe obowiązujace w Austrii, w Polsce oraz we Włoszech. W Austrii zwraca się uwagę na odmienności w samej nomenklaturze ustawowej, stosowanej względem sędziów sądów administracyjnych, którzy określani są mianem członków (Mitglieder) ${ }^{37}$. Sędziowie Bundesverwaltungsgericht oraz Bundesfinanzgericht podlegaja postanowieniom ustawy o stosunku służbowym sędziów, prokuratorów oraz urzędników sądowych ${ }^{38}$, z uwzględnieniem wszakże odmienności, o których stanowią przepisy części 5 tego aktu

30 Schulze-Fielitz (2018): 59; Kofler, Summersberger (2014): 626.

31 Schulze-Fielitz (2018): 32, 36. Powód ten został uznany za najważniejszy w ocenie $68 \%$ sędziów niemieckich sądów administracyjnych dla utrzymania rozbudowanej struktury tych sądów. Zob. Mann (2011): 36.

32 Millgramm (2008): 826. Sendler wskazuje w tej materii na doświadczenie w ramach administracji publicznej albo w innych gałęziach sądownictwa. Zob. Sendler (1983): 1453.

33 Ragnemalm (1991): 50-52; Bell (2006): 237-239; Carlson (2019): 35-38.

34 Stipo (1997): 267-288; Fraenkel-Haeberle, Urania-Galetta (2019): 300-305.

35 § 11: 6 aktu o formie rządu (Regeringsform) z 28 lutego 1974 r., SFS 2011:109.

36 Fraenkel-Haeberle, Urania-Galetta (2019): 303-304.

37 Kodek jako przykład wskazuje § 2 Bundesverwaltungsgerichtsgesetz (BGBl. I nr. 51/2012), który stanowi, że sąd ten składa się z prezydenta, wiceprezydenta oraz pozostałych członków. Szerzej zob. Kodek (2017): 32.

38 Bundesgesetz über das Dienstverhältnis der Richterinnen und Richter, Staatsanwältinnen und Staatsanwälte und Richteramtsanwärterinnen und Richteramtsanwärter (BGBl. 1961, nr 305 ze zm.). 
prawnego $^{39}$. Na uwagę zasługuje brzmienie $§ 207$ ust. 1 pkt 4 przywołanej ustawy, w którym sformułowana została jedna z przesłanek powołania na urząd sędziowski, stosownie do której kandydat powinien nadawać się do pełnienia obowiązków sędziowskich zarówno z osobistego, jak i fachowego punktu widzenia. Treść tej przesłanki jest w wysokim stopniu niedookreślona, a tym samym niełatwo zastosować ja w indywidualnym przypadku. Niemniej trudno byłoby zanegować dążenie ustawodawcy austriackiego do zapewnienia wysokiego poziomu orzecznictwa tamtejszych sądów administracyjnych. Dodatkowo kandydaci do urzędu sędziego w Bundesfinanzgericht powinni ukończyć właściwe studia, które odpowiadają działalności tego sądu, a także legitymować się 5-letnim doświadczeniem zawodowym ${ }^{40}$.

Zbliżone do przedstawionego rozwiązania ma brzmienie art. $6 \S 1$ pkt 6 p.u.s.a., stosownie do którego kandydat na stanowisko sędziego wojewódzkiego sądu administracyjnego powinien wyróżniać się wysokim poziomem wiedzy w dziedzinie administracji publicznej oraz prawa administracyjnego oraz innych dziedzin związanych z działaniem organów administracji publicznej. W doktrynie wyjaśniono, że wymóg ten jest konieczny do zagwarantowania wysokiego poziomu orzecznictwa sądów administracyjnych ${ }^{41}$, aczkolwiek podobnie jak w przypadku regulacji austriackiej ocena tego kryterium u poszczególnych kandydatów na stanowisko sędziowskie jest trudna do przeprowadzenia.

Ocena taka dokonywana jest natomiast we Włoszech w postaci egzaminu państwowego ze znajomości prawa administracyjnego, któremu podlegają kandydaci na sędziów sądów administracyjnych. Do tego egzaminu moga przystapić sędziowie sądów powszechnych oraz przedstawiciele innych zawodów prawniczych, po upływie przewidzianego okresu praktyki ${ }^{42}$. Egzamin składa się zarówno z części pisemnej, jak i ustnej ${ }^{43}$. Jego pozytywne złożenie ujmowane jest w kategoriach gwarancji należytej znajomości teorii i praktyki prawa administracyjnego, niezbędnej do wykonywania zawodu sędziego w sądzie administracyjnym ${ }^{44}$.

Tymczasem pomimo rozbudowanej struktury sądownictwa administracyjnego, traktowanej przez przedstawicieli doktryny niemieckiej w kategoriach

39 Oprócz mianowania na urząd sędziowski dotyczą one spraw dyscyplinarnych, uposażenia sędziowskiego oraz wykonywania obowiązków służbowych poza miejscem pracy.

${ }^{40}$ Inaczej kształtuje się regulacja dotycząca powołania na urząd sędziego sądu administracyjnego w poszczególnych krajach związkowych. W tej materii obowiązuje prawo urzędnicze poszczególnych krajów, z uwzględnieniem wszakże szczegółowych uregulowań. Zob. Kodek (2017): 32 .

41 Hauser, Celińska-Grzegorczyk (2016): 106.

${ }^{42}$ Przykładowo, pracownicy uniwersyteccy muszą legitymować się 5-letnim doświadczeniem zawodowym w pracy na uczelni. Adwokaci muszą mieć 8-letnie doświadczenie pracy w zawodzie. Zob. art. 14 ustawy z 6 grudnia 1971 r. o ustanowieniu regionalnych sądów administracyjnych (n. 1034; dostępna na: <https:/www.normattiva.it/uri-res/N2Ls?urn:nir:stato:legge:1971-12-06;1034!vig=> [dostęp: 15.12.2019]).

${ }^{43}$ Maddalena (2019): 2-4.

44 Fraenkel-Haeberle, Urania-Galetta (2019): 303-304. 
unikatowości ${ }^{45}$, w niemieckim systemie prawnym nie doszło do wykształcenia odrębnych przesłanek naboru na stanowisko sędziego sądu administracyjnego $^{46}$. W nauce niemieckiej obecny jest pogląd wysuwający na czoło zawód sędziowski jako taki, bez równoczesnej koncentracji na sądzie, w którym jest on wykonywany ${ }^{47}$. Niemniej w ramach aplikacji (Referendariat) kandydaci do urzędu sędziowskiego zobowiązani są do odbycia przynajmniej 3-miesięcznej praktyki w organie administracji publicznej albo w sądzie administracyjnym ${ }^{48}$. Zbliżony pogląd prezentowany jest w Szwecji, gdzie podkreśla się znaczenie ogólnego wykształcenia sędziowskiego, czemu sprzyja model kształcenia uniwersyteckiego $^{49}$ oraz jednolity system kształcenia sędziowskiego ${ }^{50}$. Niemniej na samym etapie naboru na wolne stanowisko sędziowskie ma znaczenie doświadczenie zawodowe kandydata, w tym jego zbieżność ze specyfika pracy danego sądu ${ }^{51}$.

Mimo braku odrębnej regulacji w prawie niemieckim na uwagę zasługuje praktyka wykształcona w niektórych państwach związkowych. Przykładem w tej mierze pozostaje reguła funkcjonujacca w bawarskim ogólnym sądownictwie administracyjnym, polegająca na tym, że tak zwany sędzia na próbę (Richter auf Probe) celem uzyskania prawa do orzekania bez ograniczeń terminowych w sądzie administracyjnym (Richter auf Lebenszeit) powinien przez okres kilku lat pracować w jednym z organów administracji publicznej. System ten, określany mianem rotacji (Rotationsmodell), umożliwia sędziemu zdobycie wszechstronnej wiedzy na temat funkcjonowania administracji publicznej, celem wydawania w przyszłości „rzeczowych” i „życiowych” orzeczeń ${ }^{52}$. Zwyczaj ten nie znalazł swojego potwierdzenia w prawie pisanym. Niemniej jest on silnie zakorzeniony w praktyce działania sądów administracyjnych w Bawarii i pozytywnie oceniany w niemieckiej doktrynie ${ }^{53}$.

45 Heusch (2014): 2402-2403; Schulze-Fielitz (2018): 590.

${ }^{46}$ Próby w tym kierunku były jednak podejmowane jako kontynuacja XIX-wiecznych uregulowań obowiązujących w pruskich sądach, gdzie połowa sędziów musiała mieć uprawnienia typowo orzecznicze, sędziowskie, a druga połowa - uprawnienia do zajmowania wysokich stanowisk w administracji. Zob. Pötter (1963): 740.

${ }^{47}$ Flint (2016): 82. Zob. też Voßkuhle (2002): 680; Wenner: 19.

48 Zob. § 5b ust. 4 ustawy o sędziach z 8 września 1961 r., BGBl. I, s. 713 ze zm. Praktyka administracyjna ma na celu zapoznanie aplikantów z pracą organów administracji publicznej, zarówno w ujęciu prawnym, jak i pozaprawnym, obejmującym organizację pracy, zasady wewnętrznego kierownictwa oraz relacje pomiędzy administracją a obywatelami. Zob. Schmidt-Räntsch (2009): 152 .

49 Bell (2006): 244-245.

50 Marcusson (2019): 573-574.

${ }^{51}$ Chociaż sam proces naboru odbywa się przed specjalną komisja, w skład której wchodzą sędziowie, przedstawiciele innych profesji prawniczych oraz legislatywy, istotne znaczenie odgrywa opinia o kandydatach przedstawiana przez prezesa sądu, do którego odbywa się nabór na wolne stanowisko. Ostateczną decyzję o wyborze kandydata podejmuje rząd. Szerzej zob. Marcusson (2019): 573-574.

52 Beckstein (2004): 45

53 Schmitz (2019): 267. 


\section{SPECJALIZACJA SĘDZIÓW W SYSTEMACH NIEZNAJĄCYCH ODRĘBNEGO SĄDOWNICTWA ADMINISTRACYJNEGO}

Brak odrębnych gałęzi sądownictwa administracyjnego nie oznacza, że $\mathrm{w}$ ramach sądów powszechnych nie sa podejmowane próby specjalizacji sędziów. Odbywają się one albo przez tworzenie osobnych wydziałów orzeczniczych, albo przez innego rodzaju rozwiąania nakierowane na zapewnienie wysokiego poziomu fachowości sędziowskiej.

Rezygnacja $\mathrm{z}$ funkcjonowania osobnych sądów administracyjnych nie oznacza, że w ramach sądów powszechnych nie dochodzi do utworzenia odrębnych wydziałów, w których rozpatrywane są sprawy administracyjne. Takie wydziały funkcjonuja na Słowacji, gdzie dodatkowo sprawy administracyjne rozpatrywane są zgodnie z odrębną względem cywilnej procedurą sądowoadministracyjna ${ }^{54}$.

Praktyka wyodrębnienia wydziałów, w których rozpatrywane są sprawy administracyjne nie jest znana w Danii ani Norwegii. W literaturze duńskiej podkreśla się wprost, że wszyscy sędziowie powinni w równym stopniu być kompetentni do rozstrzygnięcia każdego rodzaju sprawy ${ }^{55}$. Mimo tego ustawodawca przewidział rozwiązanie mające na celu zapewnienie sądowi wysokiego poziomu wiedzy specjalnej, jeżeli jest ona potrzebna do rozstrzygnięcia konkretnej sprawy. Prawu norweskiemu znana jest konstrukcja sędziów ławników (lay judges), którymi w zależności od przedmiotu sprawy mogą być eksperci z danej dziedziny (expert lay judges). Sa oni powoływani do konkretnej sprawy bądź to przez sąd z urzędu, bądź z inicjatywy stron i mają takie same uprawnienia orzecznicze jak sędziowie zawodowi ${ }^{56}$. Przedstawiona praktyka, obok przeprowadzania dowodu z opinii biegłego, traktowana jest jako główne źródło zapewnienia sądowi specjalistycznej wiedzy ${ }^{57}$.

Skupiając uwagę na dowodzie z opinii biegłego, do jego istoty należy potrzeba skorzystania z wiedzy specjalistycznej podmiotu, który jest w nią wyposażony, celem rozstrzygnięcia konkretnego zagadnienia ${ }^{58}$. Zważywszy na kasacyjne uprawnienia orzecznicze sądów administracyjnych w wielu państwach, w regulacjach procesowych dopuszczalność przeprowadzenia dowodu z opinii biegłego została niekiedy wyłączona ${ }^{59}$. Tam jednak, gdzie przeprowadzenie takiego dowodu jest prawnie możliwe, przykładowo w Szwecji, sądy administracyjne uzyskują istotne źródło wiedzy specjalistycznej.

Zarówno w modelu z wyodrębnionym sądownictwem administracyjnym, jak i przy jego braku, istotną rolę dla specjalizacji sędziowskiej odgrywają

${ }^{54}$ Bröstl, Gajdošíková (2015): 295-297.

${ }^{55}$ Zahle (2007): 561-562.

${ }^{56}$ Zob. Section 9-12 Act relating to mediation and procedure in civil disputes; <https://lovdata.no/dokument/NLE/lov/2005-06-17-90> [dostęp: 23.07.2019].

${ }^{57}$ Sperr (2009): 70.

${ }^{58}$ Bochentyn (2018): 59-60.

${ }^{59}$ Przykładem w tej materii jest art. $106 \S 3$ p.p.s.a., na mocy którego postępowanie dowodowe przed polskimi sądami administracyjnymi zostało ograniczone do dowodu z dokumentu. 
szkolenia i warsztaty adresowane do sędziów. W doktrynie wskazuje się na potrzebę regularnego ich odbywania, która nie powinna podlegać ograniczeniu ze względu na mniejszą ilość dni poświęcanych na orzekanie ${ }^{60}$.

\section{MINUSY ZBYT DALEKO POSUNIĘTEJ SPECJALIZACJI SĘDZIÓW}

Akcentowanie konieczności specjalizacji sędziów rozpoznających sprawy administracyjne nie oznacza, że w nauce nie są formułowane poglądy przemawiające przeciwko tego rodzaju praktyce, czy też przeciw jej nadmiernemu uwypuklaniu. W ostatnich latach stały się one szczególnie wyraźne w doktrynie niemieckiej, gdzie sądownictwo administracyjne cechuje się daleko posuniętą specjalizacją. Nie brakuje w Niemczech głosów postulujących potrzebę połączenia w jedną gałąz ogólnych sądów administracyjnych, sądów socjalnych oraz finansowych ${ }^{61}$. Jako argumenty podaje się zbyt daleko posunięta specjalizację sędziów (Überspezialisierung), która ogranicza perspektywę oglądu całego systemu prawa ${ }^{62}$. Rozwijając tę myśl, wskazano w innym miejscu, że również inne podgałęzie prawa administracyjnego, takie jak ochrona środowiska czy prawo regulacyjne, wymagałyby szczególnej wiedzy od sędziów oraz odpowiedzialnego orzecznictwa. Cel ten może zostać osiagnięty w prostszy sposób aniżeli przez rozbudowę systemu sądownictwa, a mianowicie przez kreację wydziałów i składów orzekających w sądach ${ }^{63}$. Połączenie osobnych struktur sądownictwa przyczyniłoby się do zwiększenia elastyczności obsady personalnej, a tym samym do oszczędności finansowych ${ }^{64}$. Ostatnie powody wymieniane sa przez innych autorów jako argument przemawiający za kreacją odrębnych gałęzi sądownictwa ${ }^{65}$. Formułowane są także stanowiska negujące związek szybkości postępowania oraz oszczędności finansowych w sądownictwie od struktury organizacyjnej, w jakiej ono funkcjonuje ${ }^{66}$.

Jako ujemną stronę istnienia odrębnych gałęzi sądownictwa administracyjnego wskazuje się także na ograniczone możliwości awansowe dla sę-

60 Millgramm (2008): 826.

${ }^{61}$ Postulaty tego rodzaju znajdują swoje przełożenie na inicjatywy organizacyjne organów władzy publicznej. W 2003 r. z inicjatywy ministrów sprawiedliwości krajów związkowych doszło do powołania grupy roboczej, której celem było podjęcie refleksji nad nową strukturą sądownictwa. Zob. Hufen (2009): 405-407. W połowie 2004 r. kraje związkowe Badenii-Wirtembergii oraz Saksonii przygotowały projekt ustawy umożliwiający łączenie sądów administracyjnych na poziomie krajów związkowych. Zob. Wittreck (2005): 211. Na temat wysiłków zmierzających do ujednolicenia przebiegu postępowania przed sądami administracyjnymi zob. Rieß (1991): 17-19.

${ }^{62}$ Hufen (2009): 421. Ten sam argument obecny jest w nauce norweskiej. Zob. Sperr (2009): $70-71$.

63 Gärditz (2010): 341.

64 Wittreck (2005): 215. Por. Spanner (1963): 737.

${ }^{65}$ Akcentuje się w tej mierze odciążenie od rozpatrywania spraw przez inne sądy, a także wyrównanie obciążeń orzeczniczych pomiędzy sądami i sędziami, przy niskich kosztach infrastrukturalnych. Zob. Kofler, Summersberger (2014): 625-626.

66 Steger (2008): 104. 
dziów ${ }^{67}$. Prosta struktura sądownictwa nie musi być jednak postrzegana wyłącznie w kategoriach pejoratywnych. Wprost przeciwnie, ma ona swoje zalety natury organizacyjnej. Poza tym istotniejsze znaczenie od możliwości awansu zawodowego czy też zajmowania stanowisk funkcyjnych w sądach ma ich pozycja ustrojowa względem innych gałęzi sądownictwa, w tym między innymi wysokość uposażenia sędziowskiego.

Postulaty połączenia w jeden organizm ogólnych sądów administracyjnych z sądami socjalnymi oraz finansowymi wymagałyby zmiany art. 95 ust. 1 $\mathrm{GG}^{68}$. Do tej pory podejmowane w tym kierunku działania nie doczekały się pozytywnego finału, co jest dowodem zarówno istnienia zakorzenionej tradycji rozbudowanej struktury sądownictwa administracyjnego w Niemczech, jak i wagi argumentów, które przemawiają za jej utrzymaniem.

\section{PODSUMOWANIE}

Z przeprowadzonej analizy wynika wniosek o występowaniu różnych form specjalizacji pośród sędziów, nakierowanych na zapewnienie wysokiego poziomu orzecznictwa, uwzględniającego znaczny poziom skomplikowania regulacji prawnej, potrzebę sprawnego funkcjonowania państwa oraz ochronę praw jednostki. Specjalizacja sędziowska w różnym natężeniu występuje we wszystkich poddanych analizie porządkach prawnych.

Poziom specjalizacji sędziowskiej zależy od kilku czynników, w tym natury historycznej, kulturowej oraz praktycznej. W tym ostatnim ujęciu na uwagę zasługuje liczba spraw rozpatrywanych przez sądy w poszczególnych państwach. Jeżeli spraw natury administracyjnej jest stosunkowo mało, to nie istnieje uzasadnienie daleko posuniętej specjalizacji sędziowskiej ${ }^{69}$. Gdy natomiast spraw tych jest znacznie więcej, wówczas potrzeba specjalizacji wzrasta $^{70}$.

Z przeprowadzonych rozważań wynika, że poszczególne państwa kłada duży nacisk na pozyskiwanie sędziów spośród pracowników administracji pu-

${ }^{67}$ Millgramm (2008): 827.

${ }^{68}$ Heusch (2014): 2405-2406.

${ }^{69}$ Przykładem państwa, w którym liczba spraw rozpatrywanych w sądach jest stosunkowo niewielka, pozostaje Norwegia. Opierając się na danych uzyskanych z Narodowej Administracji Sądowej w Trondheim, do sądów norweskich rocznie wpływa pomiędzy 15000 a 20000 spraw określanych mianem „cywilnych”, w których zawierają się także sprawy administracyjne. Zob. odpowiedź Dyrektora Narodowej Administracji Sądowej Iwara Anstada z 8 maja 2019 r., uzyskana w związku z badaniami naukowymi prowadzonymi pod nr UMO-2018/30/E/HS5/00421, maszynopis w posiadaniu autora.

${ }_{70}$ Tytułem przykładu, niemieckie ogólne sądy administracyjne I instancji w 2017 r. rozpoznały 203426 spraw. Na kolejny rok do rozpoznania pozostało 338078 spraw. Zob. Rechtspflege. Verwaltungsgerichte 2017. Statistisches Bundesamt 2018: 14. Z kolei sam tylko Bundessozialgericht w 2017 r. załatwił 2760 spraw, w tym 347 rewizji. W 2018 r. załatwiono 2396 spraw, w tym 318 rewizji. Zob. Die Tätigheit des Bundessozialgerichts im 2018, Kassel 2018: 11. W Bundesfinanzhof w 2018 r. załatwiono 2.116 spraw, w stosunku do wpływu wynoszaccego 2344 . Zob. <https://www.bundesfinanzhof.de/service/jahresberichte?tid=118> [dostęp: 22.07.2019]. 
blicznej. Argumentuje się w tej materii, że sędziowie tacy znają sposób funkcjonowania administracji od wewnątrz, wiedza, jakie sa jej potrzeby i możliwości ${ }^{71}$. W Polsce trend ten występuje w niewielkim zakresie. Wydaje się, że w świetle przesłanki wyróżniania się kandydata na stanowisko sędziowskie wysokim poziomem wiedzy $\mathrm{w}$ dziedzinie administracji publicznej oraz prawa administracyjnego, o czym stanowi art. $6 \S 1$ pkt 6 p.p.s.a., powyższa uwaga zasługiwałaby na głębszą refleksję osób mających wpływ na nabór na wolne stanowiska sędziowskie $\mathrm{w}$ rodzimym sądownictwie administracyjnym. Być może warte rozważenia byłoby wprowadzenie, na wzór włoski, osobnego egzaminu sędziowskiego dla kandydatów na sędziów w sądach administracyjnych. Tak samo jak we Włoszech, sądownictwo administracyjne cieszy się dużym uznaniem $\mathrm{w}$ środowisku prawniczym, czego wyrazem jest chociażby spore zainteresowanie wolnymi stanowiskami sędziowskimi. Wprowadzenie egzaminu sprawdzającego poziom wiedzy kandydatów z zakresu prawa administracyjnego nie tylko uczyniłoby bardziej realnym obowiązywanie w praktyce art. $6 \S 1$ pkt 6 p.p.s.a., lecz przede wszystkim pozytywnie wpłynęłoby na orzecznictwo sądowe.

Powracając do wyrażonej na wstępie tezy, wobec rozrostu regulacji prawnoadministracyjnej oraz rosnącego oczekiwania społecznego względem całego sądownictwa należy się spodziewać podejmowania dalszych procesów specjalizacyjnych, polegających na tworzeniu mniejszych jednostek organizacyjnych $\mathrm{w}$ ramach istniejących gałęzi sądownictwa. Trzeba ufać, że będą one sprzyjały nie tylko fachowości orzecznictwa, lecz także jego akceptowalności oraz jednolitości.

Wojciech Piqtek

Uniwersytet im. Adama Mickiewicza w Poznaniu

wojtekp@amu.edu.pl

https://orcid.org/0000-0002-3494-1912

Beckstein, G. (2004). Die Ressortierung der Verwaltungsgerichtsbarkeit in Bayern beim Innenressort, [w:] Festschrift zum 125-jährigen Bestehen des Bayerischen Verwaltungsgerichtshofs. München: 40-51.

Bell, J. (2006). Judiciaries within Europe: A Comparative Review. Cambridge.

Bochentyn, A. (2018). Dowód z opinii biegłego w jurysdykcyjnym postępowaniu administracyjnym. Gdańsk, maszynopis rozprawy doktorskiej.

Brohm, W. (1991). Stellung und Funktion des Verwaltungsrichters. Die Verwaltung 2: 137-167.

Bröstl, A., Gajdošíková, L. (2015). Die Verwaltungsgerichtsbarkeit in der Slowakei. Osteuropa Recht 3: 286-297.

Carlson, L. (2019). The Fundamentals of Swedish Law. Lund.

Górski, M. (2014). System przepisów prawa ochrony środowiska, [w:] M. Górski (red.), Prawo ochrony środowiska. Warszawa: 45-47.

Faber, R. (2013). Verwaltungsgerichtsbarkeit. Wien.

${ }^{71}$ Sendler (1983): 1454. Z badań przeprowadzonych pod kierunkiem Manna (2011: 34-35) wynika, że $52 \%$ niemieckich sędziów orzekających w sądach administracyjnych upatruje najlepszych kandydatów do pracy w tych sądach w urzędnikach administracji publicznej. Tak samo zob. Pötter (1963): 741-743. 
Flint, T. (2016). Anforderungen an Richter der Sozialgerichtsbarkeit und Selbstverständnis. Neue Zeitschrift für Sozialrecht 3: 81-84.

Fraenkel-Haeberle C., Urania-Galetta, D. (2019). Verwaltungsgerichtsbarkeit in Italien, [w:] A. von Bogdany, P.M. Huber (Hrsg.), Handbuch Ius Publicum Europaeum. Band 8: Verwaltungsgerichtsbarkeit in Europa: Institutionen und Verfahren. Heidelberg: 269-342.

Gärditz, K.F. (2010). Die Rechtswegspaltung in öffentlich-rechtlichen Streitigkeiten nichtverfassungsrechtlicher Art. Die Verwaltung 43: 309-347.

Hauser, R., Celińska-Grzegorczyk, K. (2016). Sądy administracyjne a system sądownictwa powszechnego, [w:] R. Hauser, Z. Niewiadomski, A. Wróbel (red.), System prawa administracyjnego. Tom 10: Sądowa kontrola administracji. Warszawa: 99-131.

Hermanns, C.D. (2002): Einheit der Verwaltungsgerichtsbarkeit. Osnabrúck.

Heusch, A. (2014). [Komentarz do art. 95], [w:] H. Hofmann, H.G. Henneke (Hrsg.), Kommentar zum Grundgesetz. Köln.

Hohenecker, L.L. (2015). Die neue österreichische Verwaltungsgerichtsbarkeit aus rechtsvergleich ender Sicht. Wien.

Holoubek, M. (2017). Alte und neue Grundfragen der Verwaltungsgerichtsbarkeit, [w:] M. Holoubek, M. Lang (Hrsg.), Grundfragen der Verwaltungs- und Finanzgerichtsbarkeit. Wien: 1-21.

Hufen, F. (2009). Ist das Nebeneinander von Sozialgerichtsbarkeit und Verwaltungsgerichtsbarkeit functional und materiell Begründbar? Deutsche Verwaltung 42: 405-437.

Izdebski, H. (2019). Wstęp, [w:] H. Izdebski, J.M. Zieliński, Prawo o szkolnictwie wyższym i nauce. Komentarz. Warszawa.

Jabloner, C. (2001). Rechtskultur und Verwaltungsgerichtsbarkeit. Juristische Blätter 3: 137144 .

Kluth, W. (2009). Die Rolle des Richters in der Verwaltungsgerichtsbarkeit vor dem Hintergrund ihres Funktionswandels, [w:] W. Kluth, K. Rennert (Hrsg.), Entwicklungen im Verwaltungsprozessrecht. Halle-Leipzig: 147-152.

Kodek, G. (2017). Verwaltungsgerichtsbarkeit und ordentlichen Gerichtsbarkeit - Gemeinsamkeiten und Unterschiede, [w:] M. Holoubek, M. Lang (Hrsg.), Grundfragen der Verwaltungsund Finanzgerichtsbarkeit. Wien: 23-43.

Kofler, G., Summersberger, W. (2014). Das Bundesgericht für Finanzen im System der Verwaltungsgerichtsbarkeit, [w:] J. Fischer, K. Pabel, N. Raschauer, Handbuch der Verwaltungsgerichtsbarkeit. Wien: 623-651.

Korzeniowski, P. (2014). O potrzebie koncepcji systemu prawa ochrony środowiska, [w:] J. Sługocki (red.), Dziesięć lat polskich doświadczeń w Unii Europejskiej. Problemy prawnoadministracyjne. Tom 1. Wrocław: 477-491.

Legomsky, S.H. (1990). Specialized Justice: Courts, Administrative Tribunals and a Cross-National Theory of Specialization. Oxford.

Maier, Ch. (2015). Der Weg zu einer eigenständigen Verwaltungsgerichtsbarkeit in der Russischen Föderation. Berlin.

Mann, T. (2011). Grundstrukturen der Verwaltungsgerichtsbarkeit in Deutschland und in der Ukraine. Göttingen.

Marcusson, L. (2019). Verwaltungsgerichtsbarkeit in Schweden, [w:] A. von Bogdany, P.M. Huber (Hrsg.), Handbuch Ius Publicum Europaeum. Band 8: Verwaltungsgerichtsbarkeit in Europa: Institutionen und Verfahren. Heidelberg: 543-599.

Mehde, V. (2010). Verwaltungskontrolle als daueraufgabe der Verwaltungsgerichtsbarkeit. Die Verwaltung: 379-404.

Menger, Ch.F. (1963). Zur Geschichte der Verwaltungsgerichtsbarkeit in Deutschland. Die öffentliche Verwaltung 19/20: 724-729.

Millgramm, K.H. (2008). Verwaltungsgerichtsbarkeit - neutraler Rechtsschutz für den Bürger oder Reparaturbetrieb der Verwaltung? Deutsches Verwaltungsblatt: 821-828.

Oberndorfer, P. (1983): Die österreichische Verwaltungsgerichtsbarkeit. Linz.

Pabel, K. (2013). Verwaltungsgerichtsbarkeit NEU. Wien.

Piątek, W., Skoczylas, A. (2016). Geneza, rozwój i model sądownictwa administracyjnego w Polsce, [w:] R. Hauser, Z. Niewiadomski, A. Wróbel (red.), System prawa administracyjnego. Tom 10: Sądowa kontrola administracji. Warszawa: $1-70$. 
Pötter, W. (1963). Richterauwahl und Personalpolitik in der Verwaltungsgerichtsbarkeit. Die öffentliche Verwaltung 19/20: 740-743.

Rabska, T. (2009). Prawo administracyjne a publiczne prawo gospodarcze, [w:] J. Supernat (red.), Między tradycją a przyszłością w nauce prawa administracyjnego. Wrocław: 583-592.

Ragnemalm, H. (1991). Administrative Justice in Sweden. Stockholm.

Rennert, K. (2019): Der maßgebliche Zeitpunkt der richterlichen Verwaltungskontrolle und die Funktion der Verwaltungsgerichtsbarkeit. Deutsches Verwaltungsblatt 10: 593-600.

RieB, P. (1991). Zur Reform der öffentlichrechtlichen Gerichtsbarkeit in der Bundesrepublik Deutschland. Schriftenreihe der Deutsch-Französischen Juristenvereinigung: 1-27.

Schmitz, H. (2019). Der Blick der Verwaltung auf sie Verwaltungsgerichtsbarkeit. Deutsches Verwaltungsblatt: 265-268.

Schulze-Fielitz, H. (2018). [Komentarz do art. 95], [w:] H. Dreier (Hrsg.), Grundgesetz. Kommentar. Band 3. Tübingen: 1-6312.

Sendler, H. (1983). Zur Unabhängigkeit des Verwaltungsrichters. Neue Juristische Wochenschrift 27: 1449-1458.

Serkov, P.P. (2014). Specialized courts and procedure, [w:] V. Lebedev, V.M. Khabrieva, Justice in the Modern Word. The Hague: 493-497.

Sienkiewicz, T. (2017). Aksjologia stosowania ustawy o ochronie zabytków i opiece nad zabytkami, [w:] J. Zimmermann (red.), Aksjologia prawa administracyjnego. Tom 2. Warszawa: 733-748.

Sperr, A.K. (2009). Verwaltungsrechtsschutz in Deutschland und Norwegen. Eine vergleichende Studie zur gerichtlichen Kontrolle von Verwaltungsentscheidungen. Baden-Baden.

Steger, A. (2008). Überlange Verfahrensdauer bei öffentlich-rechtlichen Streitigkeiten vor deutschen und europäischen Gerichten. Schriften zum Öffentlichen Recht 1105.

Steiner, U. (2012). Zum Stand des verwaltungsrechtlichen Rechtsschutzes in Deutschland. Bayerische Verwaltungsblätter: 129-134.

Steiner, W. (2014). Systemúberblick zum Modell «9+2», [w:] J. Fischer, K. Pabel, N. Raschauer (Hrsg.), Handbuch der Verwaltungsgerichtsbarkeit. Wien: 105-146.

Stipo, M. (1997). Prospects for legitimate interests versus the public administration, [w:] A. Piras (ed.), Administrative Law. The Problem of Justice. Milan: 267-288.

Tarno, J.P. (2006). Sądowa kontrola administracji publicznej, jej geneza i funkcje - pojęcia ogólne, [w:] J.P. Tarno, E. Frankiewicz, M. Sieniuć, M. Szewczyk, J. Wyporska, Sądowa kontrola administracji. Warszawa: 19-30.

Wenner, U. (2005). Die Sozialgerichtsbarkeit im Gefüge der staatlichen Institutionen, [w:] H. Bley (Hrsg.), Grundzüge der Sozialgerichtsbarkeit. Strukturen - Kompetenzen - Verfahren. Berlin: $1-350$.

Wittreck, F. (2005). Auftakt zu einer neuen Runde: die Vereinheitlichung der öffentlich-rechtlichen Fachgerichtsbarkeiten. Deutsches Verwaltungsblatt 2: 211-219.

Voßkuhle, A. (2002). Die demokratische Legitimation des Richters. Juristen Zeitung 14: 673676.

Zahle, H. (2007). Judicial opinion writing in the Danish Supreme Court (Højesteret). Scandinavian Studies in Law: 560-577.

Zimmermann, J. (2013). Aksjomaty prawa administracyjnego. Warszawa.

\section{ON VARIOUS WAYS OF CREATING THE SPECIALIZATION OF JUDGES ADJUDICATING IN ADMINISTRATIVE MATTERS}

S u m m a r y

The starting point of the study is the thesis on the need for the specialization and expertise of judges adjudicating in administrative matters. Then various methods by means of which this goal can be achieved are presented, both within a separate branch of the administrative judiciary and within the uniform system of the ordinary judiciary. The paper also indicates the negative aspects 
of excessive judicial specialization that are raised in the literature, which should not, however, negate the idea of being knowledgeable of more and more specific areas of administrative law, which is necessary for issuing lawful and socially acceptable decisions.

Keywords: right to a court; administrative judiciary; ordinary judiciary; judge's specialization; recruitment for a free judge position 